\title{
Cooperative response to societal and market challenges - the motives and stages of development of Mondragon cooperative model. A Case Study
}

\author{
Monika Tkacz*, Saioa Arando**, Agnieszka Pacut***
}

\begin{abstract}
Streszczenie: The article presents the motives and the development process of the co-operative enterprise Mondragon. The historical overview accompanied by brief description of the co-operative movement and its business activities has been mainly focused on cooperative response to societal and market challenges affecting the enterprise resilience in turbulent environments. The applied methodology is based on retrospective analysis of theoretical resources and annual reports of Mondragon. The research centre MIK [Mondragon Innovation \& Knowledge] specializing, inter alia, in cooperativism and entrepreneurship analysis has coordinated the data collection, selection and final interpretation, additionally providing valuable historical facts and updated information. The case study has unveiled the key cooperative actions throughout the Mondragon's development stages, which can be inspirational in the cross-country mutual learning process with reference to the policy objective no 2 of the Social Business Initiative launched by European Commission to increase the visibility of social economy entities and to identify good practices to be potentially reproduced, aligning social economy development process across countries.
\end{abstract}

Słowa kluczowe: social economy, co-operative, retrospective study, Basque Country, Mondragon.

\section{Introduction}

According to the latest figures released by European Commission, the social economy sector employs over 11 million people in the EU countries - about $6 \%$ of total employment [European Commission, 2016]. Moreover, recent years have seen a great interest in social economy entities across the Europe due to their significant role in tackling current economic and environmental challenges [Synthesis Report, 2015]. The increasing tension between tightening state budget constraints and growing societal needs have led to bottom up evolutions in European and even in global context searching for ways to scale back public expenditures, responsibilities and stimulating business activities with so-

* Monika Tkacz MIK, S. Coop.

Ibarra Zelaia Zelaigunea, 2, 20560 Oñati, Gipuzkoa e-mail: emonika24039019@gmail.com

** Saioa Arando MIK, S. Coop. Ibarra Zelaia Zelaigunea, 2, 20560 Oñati, Gipuzkoa e-mail: sarando@mondragon.edu

*** Agnieszka Pacut

Katedra Gospodarki i Administracji Publicznej Uniwersytet Ekonomiczny w Krakowie ul. Rakowicka 27, 31-510 Kraków e-mail: agnieszka.pacut@uek.krakow.pl 
cial aim [Gijselinckx, 2012, pp. 403-404]. It has stimulated the development of varied forms of social economy enterprises. However, following the findings of European Commission research [Synthesis Report, 2015] there is relatively little knowledge about the scale and characteristics of the emerging social economy entities activities and thus, the case study from the single enterprise perspective might gather importance in a form of good promotion of social economy entities practices, to support the knowledge gap fulfillment and the current process of discovery of the characteristics of entities activities across Europe to create a future guide for social innovation [European Commission, 2016].

The case study is divided into two parts. The Case Study-Part I is a retrospective study tracing back to the past of the Mondragon's experience to identify its emerging path and to detect the origins of the co-operative movement with a special focus on the Mondragon cooperative response to local societal and market challenges. The Case StudyPart II, which will be released in the forthcoming article, relates to the conceptualization of the eco-systems of Mondragon on the basis of the European Commission model ${ }^{1}$ [Synthesis Report, 2015] where its different dimensions ranging from legal, social to entrepreneurial are measured to reveal the Mondragon's framework aiming at discovering further factors of its resilience and high responsiveness towards societal and economic challenges.

The study has been prepared as a response to the main objectives of the Social Business Initiative (SBI) launched by European Commission $^{2}$ to obtain complete information

\footnotetext{
The model relates to the conceptualization of the eco-systems of social enterprises including and analysing the following elements: legal framework, social [impact] investment markets, impact measurements and reporting systems, networks and mutual support mechanisms, specialist business development and services and support, certification systems marks \& labels.

2 Three main policy objectives: no 1. to improve the access to funding for social businesses; no 2. to improve the visibility of
}

on the state and development of social economy entities in Europe and evidence for further development of the policy framework [European Commission, 2016]. However, the analysis mainly refers to the objective no 2 aimed at improvement of the visibility of social economy entities underlying additionally Action 5 concerned with development of comprehensive map to identify good practices which can be reproduced and Action 7źconcerned with mutual learning promotion [Synthesis Report, 2015].

\section{Social economy enterprises - the European context}

The origin of gradual development of social economy sector in Europe tends to be explained by old and emerging social problems resulting in an increased demand for social services, transformation of public management mechanisms, re-orientation in the area of employment and labour market and the current (re)discovery of cooperative or entrepreneurial initiatives aimed at common welfare improvement [Anheier 2006, pp. 199211; OECD 1999; Gijselinckx, 2012, p. 403]. It provides the theoretical framework for the analysis of Mondragon by the general concept of social entrepreneurship. The term appeared in the literature in the 1990s [Brock, Kim, 2011] and describes the activities of individuals, organizations as well as processes involving manufacturing and perpetuation of social values undertaken for the benefit of society, focused on innovation and change, and influenced by their external environment [Brouard, Larivet, 2010].

The substantial diversity in economic and welfare contexts, legal frameworks and cultures associated with the emergence of social enterprise in nations and regions has initiated the development of operational defi-

social businesses; no 3. to improve the legal environment of social businesses [Synthesis Report, 2015]. 
nition with reference to the European context [Synthesis Report, 2016]. In Europe, social entrepreneurship is seen as part of social economy and is described using such terms as social enterprise or social economy enterprise ${ }^{3}$. Importantly, European Union highlights the need of terminological and contextual distinction between social enterprises and social economy entities/enterprises where accurate types of enterprises are categorized either as social enterprises group or social economy entities, taking into account that some entities operating in the area of social economy exceed the social enterprise scope and the differentiation is substantial to avoid further scientific confusions [Mapping Study, Country Report: Spain, 2015, p. 21]. It gathers high importance in the context of the conducted case study and it will be further explained (see section 2).

The European Commission defines social economy initiatives as: 1 ) those for which the social or societal objective of the common good is the reason for their commercial activity, often in the form of a high level of social innovation, 2) those where profits are mainly reinvested with a view to achieving this social objective, and 3) where the method of organisation or ownership system reflects their mission, using participatory principles or focusing on social justice [COM 2011/682]. Social economy initiatives are distinguished by their democratic governance structure, the involvement of a wide range of shareholders [stakeholders] [CIRIEC 2000; Moulaert, Nussbaumer, 2005] and their ethos understood as a focus on mutual, common or public interest [Smith, Teasdale, 2011]. Due to

\footnotetext{
3 The English-language literature also employs other terms to describe activities of this kind, e.g.: social entrepreneurial venture [Austin et al., 2006], community enterprise [Nelson et al., 2005; Nwankwo et al., 2007], social firms [Jeffrey, 2005], social business [Yunus, 2007], green entrepreneurship, non-profit start-ups, environmental entrepreneurship, social justice, green entrepreneurship, sustainable entrepreneurship [quoted from Neck et al., 2009, p. 14], civic entrepreneur [Henton et al., 1997], and public entrepreneurship [Drayton, 1986].
}

the above, it is said that enterprises belonging to the social economy sector operate at the crossroads of market, public policies and civil society [Nyssens, 2006].

The European Commission country report of Spain [Mapping Study, Country Report: Spain, 2015] unveils that Spain is one of the EU countries with the widest recognition of the concept of social economy. The concept is regulated by Law 5/2011 and defined as the designation for the set of economic and entrepreneurial activities that are carried out in the private scope by those that pursue the collective interest of the members, whether the general economic or social interest or both [ibidem, p. 2]. The decentralised nature of the Spanish state builds a diverse social economy movements involving regional Autonomous Communities that have also exclusive competences in some crucial issues related to social economy. The concept of social economy in Spain is divided into two subcategories: (1) Market social economy, which is set of private, formally-organised enterprises, with autonomy of decision and freedom of membership, created to meet their members' needs through the market, by producing goods and providing services, insurance and finance, where decision-making and any distribution of profits or surpluses among the members are not directly linked to the capital or fees contributed by each member, where each member has one vote, and where democratic and participative decision-making processes is implemented; (2) 'Non Market' social economy which includes private, formally-organised organisations with autonomy of decision and freedom of membership that produce non-market services for households and whose surpluses, if any, cannot be appropriated by the economic agents who create, control or finance them [ibidem, p. 4].

While the social economy term is commonly used and broadly developed in Spain, the social entrepreneurship is a term not frequently used in public discourse, as only a few 
enterprises perceive themselves as social and on the other hand, social initiative co-operatives, work integration social enterprises, sheltered employment centres, associations and foundations are categorized into social enterprises but placed within the "Non Market" social economy area (see above) [ibidem, p. 21]. The rest, in a form of mutualities, worker owned companies, co-operatives (serving the interest of members/users) and fishermen's guilds are categorized into social economy entities and placed within 'Market social economy' (see above) [ibidem, p. 21].

\section{Mondragon - enabling the context of cooperative enterprise}

Spain has long tradition of social economy with broad development of cooperative movement. At the end of 2010, the number of co-operatives in Spain stood at 22,595 employing 298,514 people. The biggest number of co-operatives was reported in Cataluña accounting for $21.62 \%$ of total [Alzola, 2014, pp. 341-342].

Although cooperatives are placed within social economy sector it has become a source of tension among scholars for much of the history. While in broad perspective the cooperatives due to their social purpose match the concept of social economy, the narrow perspective is rather questioned. Co-operative enterprise has been rejected by mainstream economics and business studies because its strong social focus but it also does not fit to not-for profit sector due to its strong commercial and economic rationale. As a principle, the co-operatives should be viewed primarily as having an economic purpose but they also strongly contribute to the enhancement of the economic well-being of their members and local community [Mazzarol, Limnios, Reboud, 2014, pp. 4-14]. 'In fact, cooperatives are the only form of corporate entity with a clear entrepreneurial component where the subordination of the economic to the social is inherent in the logic of the organization and is usually stipulated by law' [Levi, Pellegrin-Rescia, 1997, p. 160].

Therefore, cooperatives are unique business models that are placed between the economically focused companies and the socially focused not-for profit enterprises [Mazzarol, Limnios, Reboud, 2014, pp. 4-14]. According to the European Commission report, in Spain, cooperatives are placed within set of private, formally-organised enterprises, created to meet their members' needs through the market by producing goods and providing services, insurance and finance, which distinguishing them from 'Non Market' social enterprises providing non-market services (see section 1) [Mapping Study, Country Report: Spain, 2015, p. 21].

Relating to the Spanish law (Law 27/1999) cooperatives are described as 'constituted by persons who decide to voluntarily join them, and who are free to leave them at any moment. These societies aim at carrying out business activities with the objective of satisfying the social and economic needs and ambitions of the members thereof. A cooperative shall have a democratic structure and functioning, on the basis of the international principles and in conformity with this law' [Mapping Study, Country Report: Spain, 2015, p. 16]. The Spanish law recognizes 12 types of cooperatives: workers cooperatives, of consumers, of housing, agricultural cooperatives, cooperatives of common exploitation of the land, cooperatives of services, of fishermen, of transport workers, of insurance, of health care, of education and of credit. In Spain, there are a number of cooperatives that lead in their sector of activities or big cooperatives operating in various sectors such as the Mondragon cooperative [ibidem, p. 16] founded in 1956, headquartered in the city Mondragon (Basque Country, northern Spain). With reference to Basque law (Law 4/1993) the co-operatives main objective is to promote the economic and social activities of its members, and to satisfy their needs. To fulfil this objective the 
members must participate actively in the enterprise, observe the co-operative principles, and attend to the community where the cooperative is located [Alzola, 2009], which might primarily explain the cooperatives responsiveness towards local issues. Additionally, cooperatives are business models that are able to establish strong strategic alliances and through collaboration they present high resilience in turbulent environments [Mazzarol, Limnios, Reboud, 2014, p. 14].

\section{Mondragon - cooperative response to societal and market challenges}

Mondragon was originally a group of mainly industrial co-operatives which subsequently has grown to include firms in other areas. By 2008, the Mondragon group comprised about 250 co-operatives, subsidiaries and affiliated organizations, including 73 manufacturing plants [Arando et al., 2010, p. 2]. In co-operatives in Basque Country 54,608 people were employed in 2010 and most of the employees $(31,794)$ worked for companies belonging to the Mondragon Group [Alzola, 2014, pp. 341-342]. In 2011 the number of co-operatives in the Basque Country increased by 125 [Alzola, 2014, p. 342] and according to the last data from 2014 the number of workers employed in co-operatives in Basque Country slightly increased to 54.954 [Ministerio de Empleo y Seguridad Social, 2014]. The example of Mondragon group is perceived as one of the several factors contributing to the cooperative model expansion in the Basque region [Alzola, 2014, p. 342].

The Mondragon's project began by emphasizing employment, solidarity and education. [Flecha, Santa Cruz, 2011]. The co-founder Jose María Arizmendiarrieta ${ }^{4}$ has initiated

4 J.M. Arizmendiarrieta - a priest that played a key role in the origin, growth and consolidation of Mondragon companies, both intellectually and practically. He was an advanced visionary as he imagined and developed economy that would the new perception on the enterprise where social and economic streams are efficiently balanced making workers the leading figures in their own destiny in the economic and social management of the company [Fernández, 2014].

The Mondragon's origins and the movement phenomenon can be better understood by quoting the words of the co-founder Arizmendiarrieta: 'Nothing differentiates people as much as their respective attitudes to the circumstances in which they live. Those who opt to make history and change the course of events themselves have an advantage over those who decide to wait passively for the results of the change'[Flecha, Santa Cruz, 2011, p. 158]. It perfectly describes the circumstances from which the Mondragon has emerged underlying members' willingness to cooperate and unite forces overcoming tough times after the Spanish civil war, showing a co-operative response to external socio-economic regional issues. The post-war time became an impulse for the Mondragon's emergence whose intense economic activities were dedicated to the strong social need of the local life condition improvement.

\subsection{Background - the need and source of cooperation}

\section{The Basque region - the regional strength}

The Basque region has been strongly influential on the enterprises values, culture and further its advantages. Hence, it must be said that Basque region and its local society have pride in their equality and solidarity, which accounts for the locals' attributes. Basques are very distinct in their culture, cuisine or language from the rest of Spain proving their autonomy and strong commitment to tradition and its maintenance. The Basques are very often characterised

serve people and thus, he contributed to Mondragon experience to be created [Flecha, Santa Cruz, 2011]. 
as strongly rooted people with high sense of belonging and self-reliance mentality [Morris, 1992, pp. 3-5]. The unique Basques' attitude and regionally evoked social capital were facilitated into the formation of the cooperative assuming that it was its very significant formation base.

The Basque region suffered for the role it had played in the Civil War as the Valley of Alto Deba was a battle field from September 1936 to April 1937. Military installations in Mondragon were bombed as were other parts of the Basque region. [Altuna, 2008]. The region suffered from scarcity and hunger at the end of the war. Many basic goods such as wheat, cooking oil, and coal were rationed. It was time of Francisco Franco dictatorial governance in Spain characterized e.g. by prohibition of Basque language usage and limited autonomy [Ormaechea, 1993]. There was virtually no schooling available for children over 12 years old. Mondragon early leaders sought to overcome these challenges by rallying local people to build their own alternative grounded in human-cantered values [Lafuente, Freundlich, 2012]. The postwar period was seen as a new 'dragon' that the Basques started to co-operatively 'fight' against [Flecha, Santa Cruz, 2011]. The uncomfortable circumstances were the reason to seek solutions but the local co-operative movement was triggered by four issues back in the 1940s: scarce opportunities for education, large-scale unemployment and poverty, socioeconomic inequality, and a commitment to integrate humanist values into business [Lafuente, Freundlich, 2012].

\section{The priest Arizmendiarrieta - cooperation starts through education and practice}

Some scholars [Morris, 1992; Christiansen, 2014] agree that Arizmendiarrieta allowed the co-operative spirit to be broadly developed and further embraced into a physical form of an enterprise as he was the one who was instructing locals to cooperate for the region improvement. The priest believed that while ideas might bring people apart, the needs might bring them together and he was encouraging locals to form co-operative movement against the external obstacles to reach common needs [Fernández, 2014]. The three values that the priest promoted were: cooperation, hard work and education and all of them have been enforced into Mondragon's experience [Morris, 1992, p.8]. He was strongly emphasising cooperation, however, in his viewpoint: 'One is not born a co-operator, because to be a co-operator requires social maturity, a training in social coexistence' [Morris, 1992, p. 9]. Moreover, he was convinced that 'People do not normally become co-operators spontaneously, they have to be taught the soil may be fertile but it has to be cultivated' [Morris, 1992, p. 9].

\section{Escuela Profesional Politecnica - where social capital was developed and forced to act}

According to Arizmendiarrieta: 'knowledge is power...socializing knowledge implies the democratization power' [Morris, 1992, p. 9]. He believed that education combined with cooperation and labour can bring spectacular results. The priest's greatest skill was in challenging people to do more than they thought they could while supporting their current efforts. He engaged the community in an almost continuous personal dialogue. By 1956 he had conducted over 2000 small group discussions and study session, in addition to his regular teaching schedule. The Escuela Profesional Politecnica where students were partially studying and working was a great stimulation of the locals' selfdevelopment and co-operative mindset creation [Morris, 1992, p.12]. The school itself was a co-operative as workers were involved in the school managing. Arizmendiarrieta believed that the contribution of workers in the school management would influence the democracy development in the authoritarian Spain of that time. Additionally, it became 
a place of research and innovation with developing research departments, which contributed into development of new 'co-operators' that where further accounting for the Mondragon's know-how and workers. Today, the spread of the co-operative spirit is still cultivated on the Mondragon University that was set up in 1997 in accordance with the cooperative model [Fernández, 2014] and today, it has many departments comprising around 4 thousand students.

\subsection{Overcoming socioeconomic challenges - cooperation in action}

\section{ULGOR - the first 'physical sign' of co-operative spirit}

The first visible sign of the real practice of cooperation in action is noticed in the formation of $\mathrm{ULGOR}^{5}$ in 1956. Nevertheless, it required enormous effort from the priest Arizmendiarrieta to get approval for the industrial license during the time of Franco's government where no licenses were given [Fernández, 2014]. What is more, the five pioneers, Usatorre, Larranaga, Gorronogoitia, Ormaechea and Ortubay, created a 'blind pool' of capital from the community resources and a hundred people in the community responded with pledges, basically as an expression of faith in the five pioneers and the guiding hand of José María. The pioneers purchased a firm in Vitoria that gone bankrupt but they did it for purpose: to avoid applying for permission for a new manufacturing plant; to obtain the firm's broad license authorizing it to produce a line of electrical and mechanical home appliances. The firm was further renamed Ulgor and initially housed in a Vitoria facility but on November 12, 1956, the firm moved into Mondragon town. That date is considered as the formal founding of the Mondragon's experience [Morris, 1992, pp. 13-14].

\footnotetext{
ULGOR - a co-operative considered to be the beginning of Mondragon's experience. The co-operative name is an acronym of the initials of the five funders [Morris, 1992].
}

Initially, the specific bylaws of co-operative form were not given as they were partially created after several years after the enterprise formation. Originally, the enterprise was operating as public limited company [Fernández, 2014] but with focus on democratic principles applying values of solidarity, individual economic contributions, labour contribution by all members, democratic government, progressive expansion to incorporate other workers. These have become the base of the co-operative formal model [Morris, 1992].

Ulgor manufactured a line of electrical equipment under a foreign license, and built a new factory to produce butane cookers under the brand name, Fagor. Afterwards, the set up Electronic Division became a separate company named Fagor Electronica [Fernández, 2014]. Meanwhile, a new co-operative Copreci was established to manufacture taps and safety systems for the gas stoves that Ulgor was producing [Rolland, 2006]. Just a few years after the formation of Ulgor the consumer co-operative today named Eroski was created which is the biggest retailer of Mondragon group [Fernández, 2014]. At that time Fagor S. Coop was also established (today Fagor Arrasate). The company initially focused on making dies for cutting and drawing, expanded into manufacturing metal bodies such as domestic appliances, becoming, together with Ulgor, a main driving force on the market [ibidem]. The times were mainly characterized by high rate of new co-operatives establishment, influenced by the strong dedication of the local people involved and their enthusiasms in manufacturing and changing their local socio-economic conditions [ibidem]. By the late 1960s Ulgor was the leading Spanish producer of refrigerators, by the mid1970s Ulgor had 3,500 worker-owners and it became the 'engine' which drove the co-operative's economic development, both as an internal market for the products of new cooperatives, and as a source of capital for fur- 
ther economic expansion through its surplus [Morris, 1992, p. 15].

\section{Lagun Aro - a co-operative response to lack of protection [Mondragon Corporation, 2016]}

In 1958, the 'Ministerio de Trabajo' (The Ministry of Labour) excluded all co-operatives from all social security benefits including the health benefit and retirement plan [Rolland, 2006]. During the times of lack of public protection, Lagun Aro - as a Voluntary Mutual Benefit Organization became a cooperative response to the current situation [Fernández, 2014] providing its own health insurance scheme, its own temporary and long-term disability insurance programmes, pension scheme and unemployment insurance scheme [Kerans, Drover, Williams, 1988]. Lagun Aro applies to the solidarity principle of co-operative venture, funding social security programmes of the venture members by collecting fixed premiums on earnings. In 1981 the percentage of median wage paid on premiums was $30.68 \%$. For example the premium for long term disability insurance was $0.85 \%$, for short term disability insurance $4.1 \%$ and for pension fund $10 \%$ [Kerans, Drover, Williams, 1988]. Each year the General Assembly of Lagun Aro assigns the premiums to cover the offered social security programmes. Relating to the data from 2012, 26\% of every member's gross salary goes to Lagun Aro to ensure their social needs: $18 \%$ goes to their pension, $6 \%$ to the health fund, and $2 \%$ to the Employment Fund. The Employment Fund has played a significant role during the crisis as it was used to help some co-operatives in the Group to adjust their workforce to the new situation [Alzola, 2014, pp. 353-354].

\section{Caja Laboral - a worker credit co-operative}

The Caja Laboral Popular (CLP) was the hub for the Community, the glue that tied it together, and the managerial engine that drove its development - in 1966 it had 21,653 savings accounts and by 1975 it had 190,000 savings accounts [Morris, 1992, p. 19]. The Caja Laboral became the backbone of all the coops. Arizmendiarrieta discovered that an institution registered as a workers credit co-operative could legally pay a higher interest rate on deposits than other banks and thus, the bank could attract local savings to finance cooperative expansion. In the early years of the co-operative, banking law in Spain allowed it to have slightly higher interest rates but only to invest in low interest bonds or the co-operatives [Christiansen, 2014]. Arizmendiarrieta was firmly convinced that a bank was essential for the Co-operative's survival and for local job creation. The bank supported two major processes: raising capital by overcoming the barrier to access large source of capital, and bringing about economies of scale by increased financial ability to produce and fund other co-operatives [Christiansen, 2014].

\section{Recession [1980-1986] - building the strength of Mondragon}

The time of the world oil crisis and oil price hike influenced Basque region as it was highly dependent on heavy industry [Morris, 1992, p. 22]. Until 1983 the Basque economy lost $20 \%$ of its manufacturing jobs. Unemployment rose to $18 \%$ in 1983 from $6 \%$ in 1976. For the first time in its history, the Mondragon had to deal with contraction. Moreover, it had to act without Don José María, and his instructions as he died in 1976. What is worse, it had to do so in the turbulent years after the death of Franco in 1975 [Morris,1992, p. 23]. However, the period being considered as tough was a turning point for the Mondragon's experience as it has strengthened their cooperation and empowered social cohesion, which influenced the Basques' willingness to act together leading to many structural changes and making it prepared for the prospect issues in the future. The co-operatives coped with recession by creating some financial structures and community-wide governance arrangements. 
The significant changes were introduced during the early 1980s including an unemployment insurance system, a community wide reserve fund, Inter-co-operative Solidarity Fund (FISO) or changes in the internal profit distribution formula to expand the amount of the collective reserve [Morris, 1992, p. 25]. In 1980 the co-operative group established an unemployment fund financed by a 0.5 percent payroll tax on associated co-operatives. As the economic recession worsened, this tax was eventually raised to 2.35 percent by 1986 . The broad economic base of the network plus their determination to think of themselves as a one large community helped them to keep the unemployment figures low [Kerans, Drover, Williams, 1988]. With reference to job security and willingness to keep experienced workers they started work relocation process among co-operatives, and, in 1986, 26 co-operatives received unemployment assistance [Morris, 1992, p. 23]. The crisis of the 1980's demonstrated to the co-ops that they needed more flexible labour forces. Major changes have taken place concerning the nature of membership. One central change was the creation of the "temporary member" category with most of the same rights as members but without job security. A new type of contract was created in 1993 for temporary members and it was adopted by co-operatives in the following years. However, During the 1990s, the group began to emphasize the importance of minimizing the use of temporary workers and set a goal that a minimum of $85 \%$ of the co-ops' internal work force should be made up of worker-members [Arando et al., 2010, p. 19, 32].

\section{Global crisis - further impulse for restructur- ing and strengthening}

The global crisis that started in 2008 was the time of Mondragon's model further examination. Mondragon tackled a tough, complicated year of international economic crisis increasing focus on the characteristics of their co-operative nature, innovation, internationalization, solidarity and commitment of everyone in their capacity as members and workers. It was time of significant adjustment, structural and strategic measures, taken to improve the co-operatives' competitiveness to cope with the complicated economic situation and emerge even stronger from the turbulent environment [Fernández, 2014].

The priority was to regain Mondragon's ability to generate employment, as the employment figures had fallen for the first time [by $8.4 \%$ ] and the average number of jobs was 85,066 . Faced with this situation, many co-operatives were forced to adjust their capacity, through labour force adjustment plans, moving schedules and managing relocations. The global financial and economic crisis then took a massive toll, and investment declined significantly in 2009 [Arando et al., 2010, p. 15]. The investments made have totalled 325 million euros, which means a $43 \%$ drop on those arranged in 2008, due to shrinking demand and the consequent underuse of existing manufacturing capacity. In spite of the unfavourable circumstances, the positive note has been that the promotion of new businesses has not been discouraged, and so 2009 has seen the introduction of five new undertakings [Annual Report, 2009]. Mondragon continued to focus on its worldwide presence, setting up factories of its own. This was also a basic tool for maintaining local employment and 8 new production plants were set up abroad. In 2009 Eroski opened 74 new stores, basically supermarkets of its own and self-service stores operated on a franchise basis [Fernández, 2014]. It seems safe to conclude that, compared with other firms, there has been less shrinkage of employment in the Mondragon co-ops during the current crisis. The data also suggest a record that is quite strong in terms of employment growth and job retention, even during times of economic crisis. In tandem with higher employment stability in Mondragon co-ops, there is 
also evidence of greater wage flexibility during crises. Several interviewees reported examples of wage flexibility during the crisis for example, members at the FAGOR group agreed to an $8 \%$ cut in wages for the period April 2009-March 2010 [Arando et al., 2010, p. 14].

In the Industrial Area, the slowdown in demand had a big effect on construction, capital goods and consumer durables. However, enterprise services and intermediate goods performed well.

In 2008 the Industrial Area posted sales figures of $€ 6.3$ million of which $58.2 \%$ were from international sales, with not such a big drop (2.2\% down on 2007) [Fernández, 2014].

Caja Laboral's financial activity was also complicated by the worsening of the global crisis, but indeed Mondragon ended 2010 with profits of $€ 178$ million, tripling those posted the previous year and back on the road to winning back industrial employment, with 1,378 more jobs. Total sales accounted for €13.9 bn (+1.2\%) (Fernández, 2014).

\section{Compulsory contribution-raising capital co-operatively}

Legally, the financial contribution of worker-members is considered to be a part of the co-operative capital increase. To join co-operative, the member must make a compulsory contribution which is equivalent to the annual lowest compensation on Mondragon's compensation scale. From 1 April 2010 until 31 March 2011 the monthly compensation at 1.0 on the scale was $€ 956.24$. There are 14 annual pay periods in Spain and hence the amount of money new member had to invest was 13,387.36. From 1 April 2011 until 31 March 2012 the monthly figure was $€ 1,041.67$; thus, the total investment of members was $€ 14,583.38$. Today the amount has increased to $€ 15,331.40 .20 \%$ of the contributions is used to pay the entree fee, and its objective is to compensate the effort and work done beforehand by the existing members and it is allocated to the compulsory reserve fund. The rest $80 \%$ increases the amount of capital [Alzola, 2014, pp. 345-347]. Apart from raising enterprises capital through member's contribution, the model is mainly aimed at raising members' commitment, community spirit [Rolland, 2006], sense of ownership and consequently, responsibility for the entity.

\section{Profit distribution - common wealth creation}

Profit distribution from the early stages was not aimed at members' private profit maximization but rather on community, fair wealth distribution and common wealth creation. The co-operatives have to allocate $20 \%$ of their benefits to the Compulsory Reserve Fund (CRF) and 10\% to the Contribution for Education and Co-operative Promotion and other purposes of public interest (COEP), for specific purposes such us, the education of the members and the workers of the co-operative, the promotion of relations among the co-operatives and the creation of new co-operatives, the diffusion of the cooperativism and the promotion of the Basque language. Mondragon co-operatives use this reserve to carry out projects in training and in education, to promote cultural activities, to develop research projects, to carry out care schemes (programs in support of the disabled, caring for the elderly, etc.) The General Assembly must allocate the rest $70 \%$ of the surplus among the members in proportion to their transactions (work, etc.) for the co-operative (patronage refunds), to create new reserve fund (voluntary reserve fund) and the reminder part (if any) to workers that are not members [Alzola, 2014, p. 348].

\section{Self-governance-responsibility for common 'unit'}

There is proven relation between organizational structure and motivation factors influencing organizational behaviour [Frantz, 2007]. Organization structure is the initiator of the workers' willingness to perform accu- 
rately and workers' effort is the variable influencing the organization performance. The Mondragon's organization culture based on e.g. democracy, ownership, participatory management, self-management and flat hierarchy might be considered as influencing workers' responsibility for their common 'unit'. It might be further assumed that it results in their motivation, commitment and effort, which consequently affects the Mondragon's outcome. It might be supported by the Rolland's [2006] research ${ }^{6}$ made in 2005 in one of the Mondragon co-operatives. The research has unveiled that workers appreciate community and decision making capacity more than earnings [ibidem], which can indicate that workers' motivation is not only reward oriented. It can be assumed that stable motivation of human capital is the effect of factors different than only financial ones, which further affects company performance.

\section{Networks and useful channels- strengthen- ing through formal cooperation}

In 1985 representatives of the various cooperatives met to increase coordination, maximize business effectiveness, foster strategic management and competitive strength and eliminate tariff barriers in preparation to enter the European Economic Community and the globalisation of the economy, and the integration of Spain into the European common market. As a result the Group Council known as Grupo Cooperativo Mondragon was set up comprising 70 co-operatives. In 1987, the 1st Mondragon Co-operative Group Congress was held approving the Basic Principles of the Co-operative Experience and the requirements for setting up the Inter-co-operative

\footnotetext{
6 Research conducted by Rolland [2006] in 2005. The research was including 10 questions for 176 adults and it was focused on hypothesis that people that have major part in decision making of the company are happier and work harder. The Q9 Having a say in decision making is more important to me than the amount of money I earn (39-strongly agree/96-agree) and Q10 I wanted to work at the Mondragon Co-operatives because I value community at work (72-strongly agree/63-agree).
}

Solidarity Fund. The Group Council constituted the first step towards the subsequent establishment of Mondragón Corporación Cooperativa (MCC) in 1991 [Fernández, 2014]. The new organisation became sectorial with 24 groups divided into divisions. Sectorial groups of co-operatives were established in order to improve the scope, efficiency and technological level via sectorial R\&D centres. It drastically changed the way that the co-operatives did business and enhanced internationalization underlying some basic requirements such as movement of staff between co-operatives, pooling of profits, fair distribution of profit or no internal competition. The structural changes have prepared Mondragon to face the challenge of expansion into European market [Fernández, 2014].

As a result of the rapid growth the number of employees going from 25,322 in 1992 increased to 92,773 in 2008. In the years between 2005-2007 as a result of facing some challenges related to globalization, Mondragon established some new strategies placing emphasis on innovation and education fostering creation of new skilled local employment and intensification of co-operative trainings for members plus adoption of more participatory management [Fernández, 2014].

One of the milestones in 2013 was the crisis of Fagor Electrodomésticos and neither the continued efforts of the partners of the co-operative itself, nor the solidarity measures of support from the rest of the group of co-operatives were enough to avoid the collapse of the Fagor Electrodomésticos activity. Nevertheless it has shown strong cooperative approach and attempt to respond cooperatively to the economic challenges. Immediately, all corporate solidarity mechanisms and relocation programmes were activated to try to find a solution to the surplus of employees created (around 2000 jobs) [Fernández, 2014]. 


\subsection{Mondragon today - the effect of cooperation}

Despite many obstacles throughout the Mondragon development process, today, it has 263 partners: 103 coops, 125 production subsidiaries, 1 mutual assistance organization, 8 foundations, 13 international departments and 13 coverage organizations [Annual Report, 2014]. It is divided into four business sectors: finance, retail, industry and research/knowledge. The retail sector consisting of Eroski Group is the leading sector employing 38.868 workers that accounts for $52 \%$ of total employment of Mondragon and in 2014 the annual sales reached $€ 6.231$ million [Annual Report, 2014].

The partners in different areas have resulted in valuable networks and information channels leading to specialization in different sectors, 467 patent families and sales at $€ 628$ million of new products in 2013 [Annual Report, 2013]. As a result of recent developments they established a new corporate innovation model based on interrelationship, cooperation and knowledge sharing between professionals with different profiles. Mondragon is a member of associations, technological alliances, foundations, agencies, technology platforms, research agents and clusters in the areas of research and innovation creating a working network and enhancing the concept of open innovation. Mondragon has 15 technology centres and 12 R\&D unites employing 1,676 full time researchers [Annual Report, 2014].

Nevertheless, relating to the last country report [Mapping Study, Country Report: Spain, 2015] and interviews, Mondragon faces today a few critical risk factors mainly connected with the negative effect of the global crisis, which has affected the deterioration of the market and difficulties in accessing credit and/or other funds. Despite the unfavourable climate, Mondragon is known by its great capacity to adjust to emerging challenges and even though the adjustments modify the model away from the founders' ideal, the capacity of the group to innovate and to make institutional changes is seen as necessary and valuable [Arando et al., 2010].

\section{Conclusion}

The case study has elaborated on the context of cooperative enterprise, on the basis of Mondragon cooperative model with a strong focus on the evaluation of the cooperative model and its advantages in response to socioeconomic challenges building its resilience in turbulent environments. The conducted study has drawn a lesson from internationally recognized Mondragon model, which can effectively contribute to the Social Business Initiative unveiling inside activities of cooperative enterprise for mutual learning purpose.

With reference to the scholars' frequent fierce discussion on the cooperative model categorization within social economy sector, the presentation of the model evaluation and its motives and scope of action on the basis of Mondragon gathers scientific value. Regardless tough circumstances and turbulent environment, Mondragon was able to constantly pursue economic and social purpose at time. Importantly, the institutional changes, internationalization and intercooperation process of Mondragon reveals the cooperative model expansion but with high purpose of socioeconomic value maintenance.

The described history of Mondragon, has discovered crucial advantages of the cooperative enterprise model needed to overcome obstacles throughout its development process. Initially, the lack of specific bylaws for cooperative model was empowered by the cultural attributes of Basque region and historical circumstances such as Spanish civil war or Franco's governance. The cultural and historical background have naturally evoked principles of cooperatives (such as solidarity, individual economic contributions, labour contribution by all 
members or democratic government) showing strong social cohesion and significant base for the formal creation of the cooperative enterprise (see section 3.1.; 3.2.).

Besides spontaneous incentives of cooperative responsiveness towards external challenges, there have appeared a few specific ones strongly related to the cooperative model features. Self-governance, decision making capacity and ownership influence internal condition of human capital that is a base of the enterprise strength to deal with external issues. The features have built high sense of belonging, loyalty and responsibility for common unit, which is a necessity while facing challenges and it has been proven during global crisis in 2008 where workers commonly agreed to freeze their wages aiming at the common unit survival rather than individual needs (see section 3.2.).

Mondragon has range of mechanisms that help solving dual, social and economic issues. The financial contribution of worker-members in a form of legally regulated compulsory contribution is considered to be a part of the co-operative capital increase. Apart from raising enterprise capital per member, the mechanism is strongly aimed at raising members' community spirit. The capitalized compulsory contribution is also a part of the retirement plan which at the initial stage of Mondragon's experience was a response to lack of Spanish public support in social services delivery. Additionally, Mondragon's profit distribution is regulated by law with respect to payment solidarity among members principle and common wealth creation, contributing to the community through investment into e.g. education of members and workers of the co-operative, promotion of relations among the co-operatives, creation of new co-operatives, diffusion of the cooperativism and promotion of the Basque language. The principle of fair wealth distribution affects well-being of worker-members and workers and increase resources to respond to the lo- cal socio-economic needs improving local life condition (see section 4.2.).

Relating to the past historical milestones such us recession, global crisis or bankruptcy of Fagor Electrodomésticos, Mondragon has examined its resilience to turbulent environments, enhancing network and intercooperation process. The significant steps were made in the area of unemployment insurance system (relocation of worker-members among cooperatives), a community wide reserve fund, Inter-co-operative Solidarity Fund (FISO) or changes in the internal profit distribution formula to expand the amount of the collective reserve (see section 3.2.).

The process of internationalization and business association with many subsidiaries and production departments abroad, has become a necessity to unblock the enterprise potential for further development. The presence abroad has influenced economies of scale and provided new target markets increasing Mondragon sales and broader recognition outside the Basque country (see section 4.3.).

The analyses have unveiled Mondragon's high economic competence shaped by numerous societal and market challenges showing that the subordination of the economic value into social is inherent to the logic of the cooperative model. Taking into consideration the Mondragon's strong economic rationale, it exceeds significantly typical not-for profit social enterprises but on the contrary with its high social purpose it also does not fit to the model of typical profit-oriented enterprise. Thus, relating to the European Commission categorization (see section 1), cooperative enterprise refers to the group of social economy entities that act within the market social economy (that is one of the subcategories of social economy in Spain) satisfying the needs of its members and contributing to the community by business activities and market services balancing social and economic purposes. 


\section{References}

\begin{abstract}
Aiken M. (2006). „Towards market or state? Tensions and opportunities in the evolutionary path of three types of UK Social Enterprise", in: M. Nyssens (ed.), Towards market or state? Tensions and opportunities in the evolutionary path of three UK social enterprises. London: Routledge.
\end{abstract}

Altuna L. (2006). La experiencia cooperativa de Mondragon. Eskoriatza, Lanki-Huhezi.

Alzola I. (2014). "The financing of Mondragon co-operatives: a legal analysis", in: T. Mazzarol, S. Reboud, E. Mamouni Limnios, D. Clark (eds.), Research Handbook on Sustainable Co-operative Enterprise. Case Studies of Organizational Resilience in the Co-operative Business Model. Cheltenham, Northampton: Edward Elgar Publishing Limited.

Alzola I. (2009). Cooperative Legislation in the Basque Country: A Specific Regulation. A Symposium-19-21 June 2009, Master of Management- Co-operatives and Credit Unions, Saint Mary's University, Halifax, N.S. Canada, [Online] Available from: http://www.smu.ca/ academics/sobey/cme-coop-legislation-and-public-policy.html.

Anheier H.K. (2006). ."Pięć tez na temat trzeciego sektora w Europie", in: Trzeci sektor dla zaawansowanych. Współczesne teorie trzeciego sektora. Wybór tekstów. Warsaw: Stowarzyszenie Klon/Jawor.

Annual Report (2009). Mondragon: Mondragon Cooperation, http://www.mondragon-corporation. com/wp-content/themes/mondragon/docs/eng/ annual-report-2009.pdf.

Annual Report (2013). Mondragon: Mondragon Cooperation, http://www.mondragon-corporation. com/wp-content/themes/mondragon/docs/eng/ annual-report-2013.pdf.

Annual Report (2014). Mondragon: Mondragon Cooperation, http://www.mondragon-corporation. com/eng/about-us/economic-and-financial-indicators/annual-report/.

Arando S., Feundlich F., Gago M., Jones D.C., Kato T. (2010). "Assessing Mondragon: Stability \& Managed Change in the Face of Globalization", William Davidson Institute Working Paper, No. 1003, http://papers.ssrn.com/sol3/papers.cfm?abstract_ id $=1726449$.

Austin J., Stevenson H., Wei-Skillern J. (2006). „SOcial and commercial entrepreneurship: Same, different, or both?", Entrepreneurship Theory \& Practice, 30.

Bacq S., Janssen F. (2011). "The multiple face of social entrepreneurship: A review of definitional issues based on geographical and thematic criteria", Entrepreneurship \& Regional Development, Vol. 23, No. 5-6.

Bornstein D. (2004). How to change the world: Social entrepreneurs and the power of new ideas. Oxford: Oxford University Press.

Brock D.D., Kim M. (2011). Social Entrepreneurship Education Resource Handbook, Ashoka U, http://asho-
kau.org/wp-content/uploads/2011/04/AshokaU_ Handbook_Preview.pdf (dostep: 12.12.2015).

Brouard F., Larivet S. (2010). „Essay of clarification and definitions of related concepts of social enterprise, social entrepreneur and social entrepreneurship", in: A. Fayolle, H. Matlay (eds.), Handbook of Research on Social Entrepreneurship. Cheltenham: Edward Elgar Publishing

Chavez R., Mazón J. (2005). The social economy in the European Union. The European Economic and Social Committee.

Christiansen A.A. (2014). Evaluating Workplace Democracy in Mondragon. UVM Honors College Senior Theses. University of Vermont, http://scholarworks. uvm.edu/cgi/viewcontent.cgi?article=1016\&conte$\mathrm{xt}=\mathrm{hcoltheses}$

CIRIEC (2000). The Enterprises and Organisations of the Third System. Strategic Challenge for Employment, Liege: The International Centre of Research and Information on Public and Cooperative Economy.

COM (2011) 682, Social Business Initiative. Creating a favourable climate for social enterprises, key stakeholders in the social economy and innovation. Brussels: European Commission.

Corporate Profile (2015). Mondragon: Mondragon Cooperation, http://www.mondragon-corporation. com/eng/about-us/economic-and-financial-indicators/corporate-profile/

Dees J.G. (1998). The meaning of social entrepreneurship. Paper. Centre for the Advancement of Social entrepreneurship, Fuqua School of Business, Duke University.

Defourny J., Develtere P. (2006).,Ekonomia społeczna: ogólnoświatowy trzeci sektor", in: Trzeci sektor dla zaawansowanych. Współczesne teorie trzeciego sektora. Wybór tekstów. Warsaw: Stowarzyszenie Klon/ Jawor.

Drayton W. (2002). „The citizen sector: becoming as entrepreneurial and competitive as business", California management review, Vol. 44, Iss. 3.

European Commission (2016). Social economy in EU, http://ec.europa.eu/growth/sectors/social-economy/index_en.htm

Fernández J.R. (2014). A review of the key milestones in the co-operative group's history. Mondragon: Mondragon Cooperation, http://www.mondragon-corporation.com/wp-content/themes/mondragon/docs/ History-MONDRAGON-1956-2014.pdf

Flecha R., Ignacio S.C. (2011). "Cooperation for Economic Success. The Mondragon Case", Analyze\&Kritik, no. 1, http://www.analyse-und-kritik.net/2011-1/ AK_Flecha_Santa-Cruz_2011.pdf.

Frantz R. (2007). Renaissance in Behavioural Economics. Essays in honor of Harvey Leibenstein. New York: Routledge.

Gijselinckx C. (2012) Cooperative Answers to Societal Challenges: 9 Insights from $2 \times 9$ Cases in: The Amazing Power of Cooperatives, Texts Selected from 
the International Call for Paper Proposals. QUEBEC International Summit of Cooperatives.

Hulgård L. (2010). „Discourses of social entrepreneurship - variations of the same theme?", Working Paper, No. 10/01, EMES European Research Network.

Kerans P., Drover G., Williams D. (1988). Welfare and Worker Participation. London: The Mackmillan Press Ltd. Lafuente J.L., Freundlich F. (2012). The Mondragon Co-operative Experience: Humanity at Work, http:// www.managementexchange.com/story/mondragon-co-operative-experience-humanity-work.

Leibenstein H. (1978). General X-Efficiency Theory and Economic Development. New York: Harvard University Press.

Mapping Study, Country Report: Spain (2015). A map of social enterprises and their eco-systems. European Commission, http://ec.europa.eu/social/BlobServlet?docld=13278\&langld=en

Mazzarol T., Limnios E., Reboud S. (2014). "An overview of the research", in: T. Mazzarol, S. Reboud, E. Mamouni Limnios, D. Clark (eds.), Research Handbook on Sustainable Co-operative Enterprise. Case Studies of Organizational Resilience in the Co-operative Business Model. Cheltenham, Northampton: Edward Elgar Publishing Limited.

Ministerio de Empleo y Seguridad Social (2014). http://www.empleo.gob.es/es/estadisticas/.

Mondragon Corporation (2016). http://www.mondragon-corporation.com/eng/.

Morris D. (1992). The Mondragon System-Cooperation at Work. Washington and Minneapolis: Institute for Local-Reliance and Infinity, http://ilsr.org/wp-content/uploads/files/images/mondragon.pdf.

Moulaert F., Nussbaumer J. (2005). „Defining the Social Economy and its Governance at the Neighbourhood Level: A Methodological Reflection", Urban Studies, Vol. 42, No. 11.
Nicholls A. (ed.) (2006). Social Entrepreneurship. New Models of Sustainable Change. Oxford: Oxford University Press.

Nyssens M. (2006). Social enterprise. At the crossroads of market, public policies and civil society. London, New York: Routledge.

OECD (1999). Social Enterprises. Paris: OECD.

OECD (2009). The changing boundaries of social enterprises. Paris: OECD.

Orhei L. (2011). „The competence of social entrepreneurship. A multidimensional competence approach", HAN Business Publication, http://han.surfsharekit. nl:8080/get/smpid:15376/DS2.

Ormaechea, J.M. (1993). The Mondragon Co-operative Experience. Mondragon: Mondragon Corporacion Cooperativa.

Peredo M., McLean M. (2005). Social entrepreneurship: a critical review of the concept, http://web.uvic.ca / aperedo/page1/assets/Social\%20Ent\%20the\%20 Concept.pdf.

Perrini F. (2006). „Social entrepreneurship domain: setting boundaries", in: F. Perrini (ed.), The New Social Entrepreneurship. What Awaits Social Entrepreneurial Ventures? Cheltenham, Northampton: Edward Elgar Publishing.

Rolland S. (2006). "Mondragon Corporation Co-operatives, People working together", UW-L Journal of Undergraduate Research, vol. IX, http://www.uwlax.edu/ URC/JUR online/PDF/2006/rolland.pdf.

Salamon L.M. (2010). „Putting the civil society sector on the economic map of the world", Annals of Public and Cooperative Economics, Vol. 81, No. 2.

Sharir M., Lerner M. (2006). „Gauging the success of social ventures initiated by individual social entrepreneurs", Journal of World Business, 41.

Smith G., Teasdale S. (2011). „Ekonomia społeczna, przedsiębiorstwo społeczne i teoria demokracji stowarzyszeniowej", Ekonomia Społeczna, no. 2.

\section{Spółdzielnia odpowiedzią na wyzwania społeczne i rynkowe - motywy i etapy rozwoju modelu spółdzielni Mondragon. Studium przypadku}

Streszczenie: W W artykule przedstawiono uwarunkowania i proces powstania spółdzielni Mondragon. Omówiono tło historyczne oraz czynniki wpływające na powstanie tej największej na świecie spółdzielni. Ponadto dokonano syntezy opisu działalności wspomnianego podmiotu.

Do realizacji celu wykorzystano metodę analizy literatury przedmiotu. Cennym źródłem informacji były raporty diagnostyczne spółdzielni Mondragon oraz dane uzyskane z centrum badawczego MIK (Mondragon Innovation \& Knowledge), specjalizującego się między innymi w monitorowaniu i diagnozowaniu przedsiębiorczości społecznej. Dostarczyło ono danych na temat historycznych aspektów działalności podmiotu oraz współcześnie osiąganych rezultatów.

Przeprowadzona analiza case study pozwoliła zidentyfikować specyficzne czynniki wpływające na sukces rozwoju niniejszej spółdzielni. Czynniki te mogą stanowić inspirację w obszarze wymiany wiedzy i praktyk w sektorze ekonomii społecznej, co nawiązuje wprost do założenia nr 2 inicjatywy Komisji Europejskiej o przedsiębiorczości społecznej. Tym samym przyczynia się do promocji dobrych praktyk w obszarze przedsiębiorczości społecznej z możliwością ich potencjalnego odtworzenia celem wyrównania poziomu rozwoju ekonomii społecznej w wymiarze międzynarodowym.

Słowa kluczowe: ekonomia społeczna, spółdzielczość, badania retrospektywne, Kraj Basków, Mondragon. 


\section{Prawa autorskie i licencja / Copyright and License}

(c) $(1 \Theta \Theta$

Artykuł opublikowano na licencji Creative Commons

Uznanie autorstwa - Użycie niekomercyjne - Bez utworów zależnych 3.0 Polska

http://creativecommons.org/licenses/by-nc-nd/3.0/pl/

This article is published under the terms of the Creative Commons

Attribution - NonCommercial - NoDerivs (CC BY-NC-ND 3.0) License

http://creativecommons.org/licenses/by-nc-nd/3.0/ 